\title{
Study on the Optimum Degradation Process of Corn Stalk
}

\author{
Tongyou $\mathrm{ZHUO}^{1,2,3}$ \\ ${ }^{1}$ Jilin Agriculture Science and Technology College, Jilin, 132101, China \\ ${ }^{2}$ National R\&D Center For Sugar Processing, Jilin, 132101, China \\ ${ }^{3}$ Brewing Technique Engineering and Research Center of Jilin Tertiary Institution, Jilin, 132101, China
}

651637824@qq.com

Keywords: Corn Stalk, Cellulase, Degradation

\begin{abstract}
Corn stalk was used as the research object to study the effect of different ratio on the degradation rate of corn stalks by cellulase addition, ratio of material to liquid, temperature and time. Then the optimum technological conditions of corn stalk degradation were screened out. The results showed that the degradation rate was $27.6 \%$ when the cellulase content was $3 \%$, the ratio of material to liquid was $1: 20$, the temperature was $45^{\circ} \mathrm{C}$ and the time was $2 \mathrm{~h}$.
\end{abstract}

\section{Introduction}

Corn Stalk is an important biological material resource in agricultural production system. The reasonable and effective utilization of corn stalk resources is of great significance to improve the sustainable development of soil fertility, soil and water conservation, ecological environment and material resources in agricultural production system. Become an important research field of agricultural sustainable development [1 4]. In this study, the enzymatic hydrolysis of corn stalks with cellulose was used as an index to optimize the enzymatic hydrolysis process by single factor experiment, so as to provide a theoretical reference for the comprehensive development and utilization of corn stalks.

\section{Materials and Methods}

Materials And Reagents. Corn stalk, the autumn of 2014 collected from the experimental field of Jilin Agriculture Science And Technology College; cellulase (CAS:9012-54-8) was purchased from a company in Shanghai, sulfuric acid, sodium hydroxide, hydrochloric acid, ammonia, acetic acid and sodium acetate were domestic analytical pure.

Experimental Method. According to the results to determine the optimal factors of single factor test, chose the amount of enzyme added $2 \%, 3 \%, 4 \%$ three levels; selection of liquid material ratio $1: 15,1: 20,1: 25$ three level; temperature was $40^{\circ} \mathrm{C}, 45^{\circ} \mathrm{C}, 50^{\circ} \mathrm{C}$ three levels; time was $1.5 \mathrm{~h}, 2.0 \mathrm{~h}, 2.5 \mathrm{~h}$ three levels. The dosage of enzyme the material liquid ratio, temperature, time, the four factors of the orthogonal designed to determine the optimum conditions of corn stalk degradation.

Data Analysis. The experimental data were processed and analyzed by Excel 2003 and Spss 17.0 software.

\section{Results and Analysis}

Influence of Material Liquid Ratio on the Enzyme Degradation. The figure 1 showed that the degradation rate increased with the increase of the ratio of material to liquid. When the ratio of material to liquid was $1: 20$, the degradation rate reached the maximum value. When the ratio of material to liquid exceeded 1:20, the degradation rate decreased Incremental trend. Because when the liquid exceeded 1:20 and gradually increased, the chance of contact of the enzyme with the substrate would be reduced, the degradation rate would be reduced. And when the ratio of material to liquid was 1:20, the chance of enzyme contact with the substrate was most suitable. 


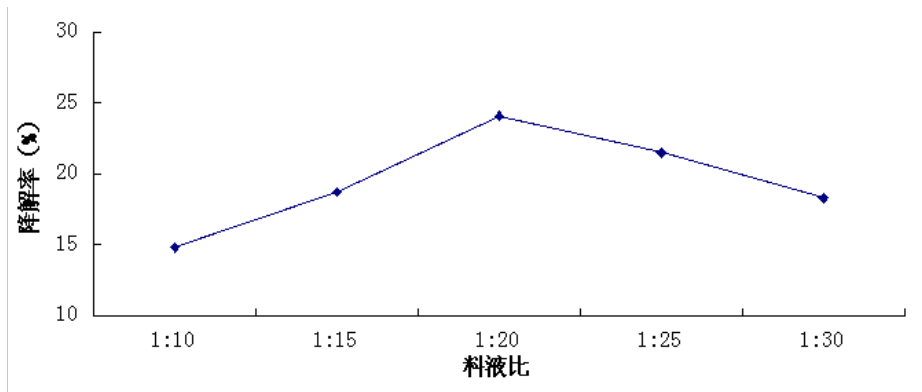

Fig. 1 Influence of material liquid ratio on the degradation effect

Influence of Temperature on Degradation. The figure 2 showed that when the temperature was $45^{\circ} \mathrm{C}$, the degradation rate reached the maximum value. When the temperature exceeded $45^{\circ} \mathrm{C}$, the degradation rate decreased and did not show an increasing trend. Mainly because the temperature not only affected the reaction rate also affected the enzyme activity, the temperature was low when the enzyme molecules and cellulose molecules to the probability of effective collision was small, and the temperature was too high, the enzyme activity decreased. The optimum temperature of the cellulase was about $45^{\circ} \mathrm{C}$, and when the temperature reached $45^{\circ} \mathrm{C}$, the activity of the enzyme was the strongest. When the temperature exceeded $45^{\circ} \mathrm{C}$, the enzyme protein was gradually denatured and the activity of the enzyme decreased gradually, resulting in a decrease in degradation rate trend.

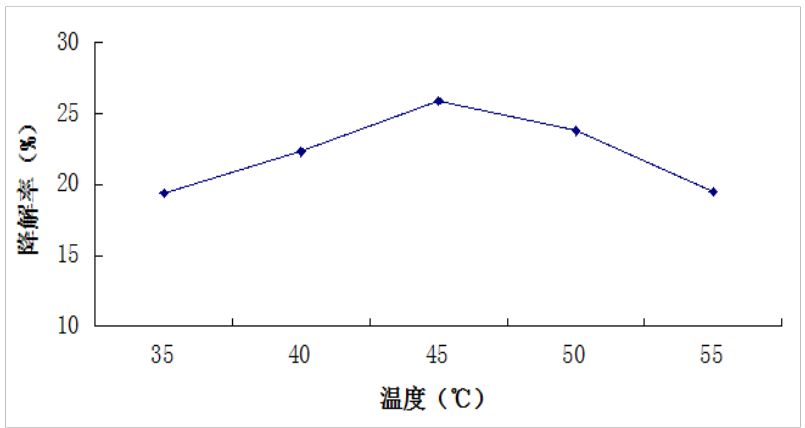

Fig. 2 Influence of temperature on the degradation effect

Influence of Time on the Degradation. The figure 3 showed that when the time was $2 \mathrm{~h}$, the degradation rate reached the maximum value. When the time was more than $2 \mathrm{~h}$, the degradation rate decreased and did not show an increasing trend. Since the reaction started with time, the enzyme molecules were sufficiently contacted with the substrate, the reaction rate increased, and when the substrate was sufficiently bound to the enzyme molecule, the effective concentration of the enzyme molecule decreased, and the reaction product had a certain inhibition on the enzymatic reaction, resulting in degradation rate also decreased.

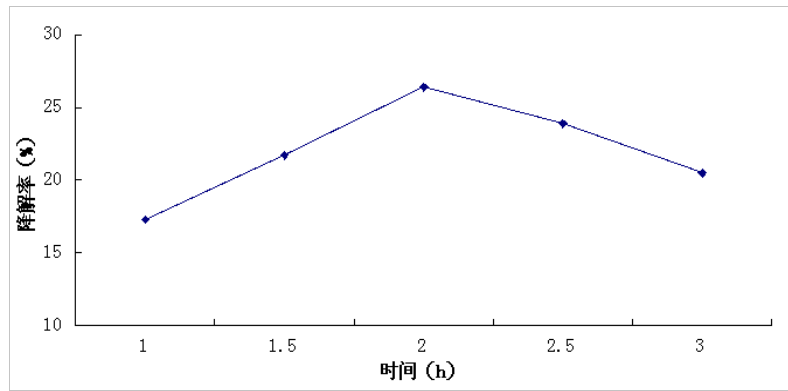

Fig. 3 Influence of time on the degradation effect

Influence of Enzyme Addition on Degradation. The figure 4 showed that when the amount of enzyme is $3 \%$, the degradation rate reached the maximum value. When the amount of enzyme was more than $3 \%$, the degradation rate did not change greatly. Because the number of binding molecules between the substrate and the enzyme molecules was limited, these junctions were all occupied by the enzyme molecules, and then increased the amount of enzyme, the new part of the enzyme molecules and the substrate could not be combined, not enzymatic action, And the increase in enzyme addition was bound to increase the cost. 
So the ratio of material to liquid $1: 20$, temperature $45^{\circ} \mathrm{C}$, time $2 \mathrm{~h}$, enzyme dosage of $3 \%$ for the single factor under the highest degradation rate.

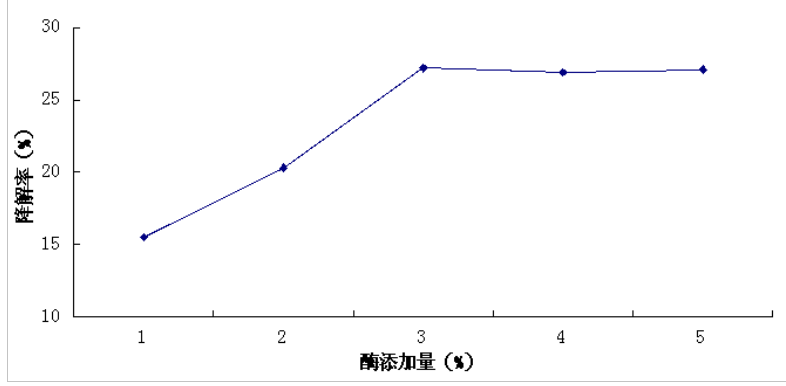

Fig. 4 Influence of the adding amount on degradation effect

Orthogonal Test Results. From the completion of the single factor test to determine the range of factors, selected the ratio of material to liquid, temperature, time, the amount of enzyme for the study of factors designed orthogonal test, the choice of L9 (34) orthogonal test factor level Table 1, to determine the enzymatic degradation the best process conditions of Corn Stalk.

The four factors of orthogonal test design were the same as the previous single factor test results. The effect of various factors on the degradation effect was the order of enzyme addition $>$ the ratio of material to liquid $>$ time> temperature, and the best process was A2B2C2D2. Under the optimum conditions, the ratio of material to liquid was $1: 20$, the temperature was $45^{\circ} \mathrm{C}$, the time was $2 \mathrm{~h}$, the effect of degradation of corn stalks was higher than that of orthogonal experiment group. The degradation rate Was $27.6 \%$.

Tab. 1 Orthogonal test table L9(34)

\begin{tabular}{|c|c|c|c|c|c|}
\hline \multirow[b]{2}{*}{ Test number } & \multicolumn{5}{|c|}{ Factor } \\
\hline & $\begin{array}{l}\text { enzyme } \\
\text { dosage } \mathrm{A} / \%\end{array}$ & $\begin{array}{l}\text { solid-liquid } \\
\text { ratio B }\end{array}$ & $\begin{array}{l}\text { Time C } \\
/ \mathrm{h}\end{array}$ & $\begin{array}{l}\text { Temperatur } \\
\text { e D } /{ }^{\circ} \mathrm{C}\end{array}$ & $\begin{array}{l}\text { degradation } \\
\text { rate } / \%\end{array}$ \\
\hline 1 & 1 & 1 & 1 & 1 & 24.8 \\
\hline 2 & 1 & 2 & 2 & 2 & 26.7 \\
\hline 3 & 1 & 3 & 3 & 3 & 25.2 \\
\hline 4 & 2 & 1 & 2 & 3 & 26.0 \\
\hline 5 & 2 & 2 & 3 & 1 & 27.1 \\
\hline 6 & 2 & 3 & 1 & 2 & 26.3 \\
\hline 7 & 3 & 1 & 3 & 2 & 24.4 \\
\hline 8 & 3 & 2 & 1 & 3 & 25.2 \\
\hline 9 & 3 & 3 & 2 & 1 & 24.5 \\
\hline K1 & 76.7 & 75.2 & 76. & 76.3 & \\
\hline K2 & 79.4 & 79.0 & 77. & 77.2 & \\
\hline K3 & 74.1 & 76.0 & 76. & 76.7 & \\
\hline k1 & 25.6 & 25.1 & 25. & 25.4 & \\
\hline k2 & 26.5 & 26.3 & 25. & 25.7 & \\
\hline k3 & 24.7 & 25.3 & 25. & 25.6 & \\
\hline $\mathrm{R}$ & 1.8 & 1.2 & 0.4 & 0.3 & \\
\hline $\begin{array}{l}\text { optimized } \\
\text { program }\end{array}$ & A2 & B2 & C2 & D2 & \\
\hline $\begin{array}{l}\text { Order of } \\
\text { factors }\end{array}$ & A & B & $\mathrm{C}$ & $\mathrm{D}$ & \\
\hline
\end{tabular}




\section{Conclusion}

In this experiment, the degradation effect of corn stalk was determined by four factors, such as ratio of material to liquid, enzyme addition, time and temperature. The results showed that the degradation rate was the highest when the ratio of material to liquid was $1: 20$, and decreased with the increase of the ratio. When the temperature was $45^{\circ} \mathrm{C}$, the degradation rate reached the maximum. With the increase of temperature, the degradation rate decreased with the increase of temperature. The degradation rate reached the maximum when the time was $2 \mathrm{~h}$. When the enzyme content was $3 \%$, the degradation rate reached the maximum value. When the enzyme content was more than 3\%, the degradation rate was not too Big change, was balanced. The results showed that the degradation rate of corn stalks was the best, and the degradation rate was $27.6 \%$. The optimum conditions were as follows: the ratio of material to liquid was $1: 20$, the temperature was $45^{\circ} \mathrm{C}$ and the time was $2 \mathrm{~h}$.

\section{References}

[1] Korontzi S, McCarty J, Loboda T, et al. Global distribution of agricultural fires in croplands from 3 years of Moderate Resolution Imaging Spectroradiometer (MODIS) data [J]. Global Biogeochemical Cycles, 2006, 20(2): 1 15.

[2]Tong Jingjing, Liu Rui, Zhang Mingshun. Current situation and policy implication for biomass energy utilization [J]. Environment and Sustainable Development, 2015,15(4): 127 129.

[3]Han Lujia ,Yan Qiaojuan, Liu Xiangyang, et al. Straw resources and their utilization in China [J]. Transactions of the CSAE, 2002, 18(3): 87 91.

[4] Zhang Bailing. Legislative policy and inspirations of foreign development and utilization of biomass energy [J]. World Environment, 2014,14 (5): 78 80.

[5] Pan Yajie, Zhang Lei, Guo Jun, et al. The study on biological degrading of crops straw [J]. Renewable Energy Resources, 2005,13 (3): 33 35. 